\title{
ANALYSIS OF DEBRIS VACUUMED FROM K-REACTOR TANK (U)
}

by E.W. Baumann

Westinghouse Savannah River Company

DE93 003321

Savannah River Site

Aiken, South Carolina 29808

Other Authors: $v / 1$

This paper was prepared in connection with work done under Contract No. DE-AC09-89SR18035 with the U. S. Department of Energy. By acceptance of this paper, the publisher and/or recipient acknowledges the U.S. Government's right to retain a nonexclusive, royalty-free license in and to any copyright covering this paper, along with the right to reproduce and to authorize others to reproduce all or part of the copyrighted paper.

\section{MASTER}




\section{DISCLAIMER}

This report was prepared as an account of work sponsored by an agency of the United States Government. Neither the United States Government nor any agency thereof, nor any of their employees, makes any warranty, express or implied, or assumes any legal liability or responsibility for the accuracy, completeness, or usefulness of any information, apparatus, product, or process disclosed, or represents that its use would not infringe privately owned rights. Reference herein to any specific commercial product, process, or service by trade name, trademark, manufacturer, or otherwise does not necessarily constitute or imply its endorsement, recommendation, or favoring by the United States Government or any agency thereof. The views and opinions of authors expressed herein do not necessarily state or reflect those of the United States Government or any agency thereof.

This report has been reproduced directly from the best available copy.

Available to DOE and DOE ( ontractors from the Office of Scientific and Technical Information, P.O. Box 62, Oak S:idge, TN 37831; prices available from (615) 576-8401, FTS 626-8401.

Available to the public from the National Technical Information Service, U.S. Department of Commerce, 5285 Port Royal Rd., Springfield, VA 22161. 
WSRC-TR-92-027

\section{WESTINGHOUSE SAVANNAH RIVER COMPANY \\ INTER-OFFICE MEMORANDUM}

January 20, 1992

TO: $\quad$ J.M. Morrison, $773-56 \mathrm{~A}$

FROM: $\quad$ E.W. Baumann, 773-41A $(5-1421)$

Technical Reviewer $\frac{\text { T. EqHere }}{\text { J.E. Marra }}$

\section{ANALYSIS OF DEBRIS VACUUMED FROM K-REACTOR TANK (U)}

\section{INTRODUCTION}

During the ultrasonic (UT) inspection of I -Reactor tank by the Equipment Engineering Section in the spring of 1990 , solid material (termed debris) was seen on the bottom of the tank. When the UT inspection was complete, a specially designed underwater vacuum cleaner was used to collect the accumulation at 17 monitor pin positions. This material was sent to SRL for characterization as an action item of the Reactor Corrosion Mitigation Committee.

Acquisition of this debris provided an opportunity to obtain first-hand information about conditions within the tank that affect corrosion conditions and/or moderator chemistry. The purpose of this memorandum is to describe the results of the analyses and the implications of what was found.

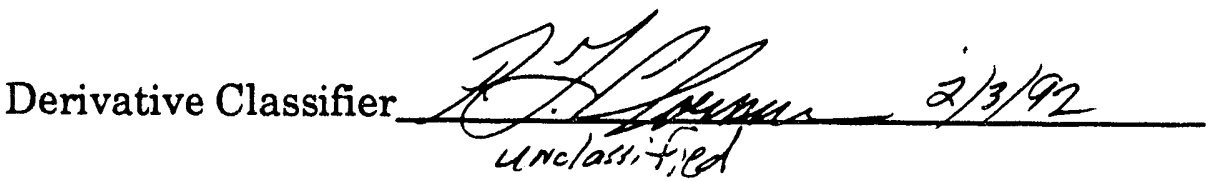




\section{SUMMARY}

Debris vacuumed from the bottom of K-Reactor tank in March 1990 was analyzed to provide information related to corrosion and moderator chemistry conditions within the tank. About 100 grams of debris were collected from the 17 positions vacuumed, including about $1 \mathrm{gram}$ of fines that had passed through the filter assembly. The most significant finding was the low chloride content of the debris $(<5$ $\mathrm{ppm}$ ), which indicates that this debris is neither a source nor a sink of chloride for the moderator system. Debris on the bottom of the tank is expected to be dispersed into the bulk moderator during flow conditions and be removed by the purification system or the evaporator.

The bulk of the filtered debris consisted of flakes of yellow material, about $20 \mu \mathrm{m}$ (1 mil) thick and up to $3 \mathrm{~mm}$ across. These flakes were mostly alumina, and their origin has been ascribed to the tank wall. A few $\mathrm{mm}$-size metal fragments, mostly stainless steel, of unknown origin, were also found. Aluminum and iron (or stainless steel) were identified as the principal elements of the material, with traces of silicon, uranium, thorium, sulfur, and phosphorus.

The crystalline components were primarily gibbsite (alumina trihydrate) with a small amount of böhmite (alumina monohydrate), which implies that the material originated mostly from a low-temperature source, and not from the fuel assemblies. The long-lived gamma emitters were activation products (Co-60, $\mathrm{Zn}-65$ ) and fission products (Ru-106, Ce-144, and Eu-154). Alpha emitters were Pu-238, $\mathrm{Pu}-239, \mathrm{Cm}-244$ and $\mathrm{Cm}-242$, remaining from past charges.

\section{DISCUSSION}

\section{Acquisition of Sample}

Material noticed during the UT inspection of the K-Reactor tank was vacuumed from the bottom of the tank in March 1990. The location of the 17 positions vacuumed is shown on the reactor face map of Figure 1. The underwater vacuum cleaner ${ }^{(1)}$ was custom-designed with a detachable filter assembly. When the vacuuming was completed, the drained filter assembly was stored in the dry holding rack in the $105-\mathrm{K}$ Process Room. The radiation level close to the container was reported to be several hundred $\mathrm{mr} /$ hour.

The filter assembly, in a shielded shipping container, was shipped to the High Level Caves at the Savannah River Laboratory on September 3, 1991. A drawing of the filter portion of the vacuum cleaner that was received at SRL is shown in Figure 2. The 60-mesh stainless steel filter was contained in an aluminum tube approximately four inches in diameter.

Prior to cutting the tube for removal of the filter, about $50 \mathrm{~mL}$ of water was drained from the assembly. Also, about a gram of fines that had passed through the filter was collected from the filter outlet. The fines were moist, with clay-like consistency. Both the water and the fines were subsequently analyzed. 
The tube was cut at the point shown in Figure 2 and the filter was withdrawn. About 100 grams of moist material was caked on the filter and loose in the tube. The material appeared granular (sand-like) with bits of metal pieces. A smaller, representative, sample of 20.4 grams was taken for analysis. The smaller sample minimized the radiation dose in subsequent handling of the material in shielded/contained areas outside the High Level Caves.

The analyses performed by the Analytical Development Section on the three samples taken (one liquid and two solid) are summarized in Table1. Results are given in the next section.

\section{Results of Analysis}

\section{Analysis of Liquid}

The liquid drained from the assembly was slightly yellow, but became water-white when the suspended solids were filtered out. Except for the gamma spectrometry, which was performed on both the filtered and unfiltered liquids, all analyses were made on the filtered liquid. The solids filtered out, which looked like rust, were not analyzed.

The primary purpose in analyzing the liquid was to determine whether or not it was moderator. The results in Tables 2 through 4 indicate it was not moderator. The density of $1.01 \mathrm{~g} / \mathrm{mL}$ (Table 2) and the tritium content of $1.41 \mu \mathrm{Ci} / \mathrm{mL}$ (Table 3) are too low for moderator. Rather it was either rinse water from the D\&E machine or disassembly basin water.

The chemical components (Table 4) indicate the water contained mostly sodium and calcium cations and sulfate and chloride anions. This composition, together with the $\mathrm{pH}$ and conductivity (Table 2) suggest that the most likely source is disassembly basin water. The radionuclides (Table 3) may have been acquired through contact with the filter container and its contents during storage.

\section{Analysis of Solids}

The same analyses were made for the fines and for the filtered solids, except that alpha spectroscopy was done only on the filtered material. The purpose of these analyses was to identify the solids, through radionuclide content, crystalline form, and elemental content.

\section{Radionuclide Content}

Gamma pulse height analysis (Table 5) showed the presence of long-lived fission products and neutron activation products. With the exception of Cs-137, which was not found in the filtered material, the quantities of radionuclides in the filtered material were 2.5 to 4 times those in the fines. The Co-60 and $\mathrm{Zn}-65$ activation products come from $\mathrm{n}, \gamma$ reactions on $\mathrm{Co}-59$ and $\mathrm{Zn}-64$. Cobalt is present in the stainless steel tank and piping; zinc is found in the aluminum rnmponents.

The alpha activity of the filtered solids (Table 6) was determined by alpha pulse height analysis counting of a leachate and of a solution of the material. The activity leached by nitric acid was primarily $\mathrm{Cm}-244$. When the material was 
nearly all dissolved by a hydrochloric-hydrofluoric mixture, the gross count increased 40 -fold, and the proportion of plutonium isotopes increased.

Table 6 includes for comparison the alpha analysis of the moderator in K-Reactor made in $1989^{(2,3)}$. The decrease in the amount of the relatively short-lived $\mathrm{Cm}-242$ since this earlier work confirms the earlier identification that this alpha-emitter was $\mathrm{Cm}-242$.

\section{Crystalline Forms}

$\mathrm{X}$-ray diffraction was used to identify the crystalline forms in both the fines and the filtered residue. The fines were primarily amorphous $;$ ith a small crystalline content. One phase was identified as gibbsite $\left(\mathrm{Al}_{2} \mathrm{O}_{3} \cdot 3 \mathrm{H}_{3} \mathrm{O}\right)$; another phase was present that did not match any standard phases in the reference database. In the filtered residue the major crystalline phase identified was also gibbsite, plus a trace of böhmite $\left(\mathrm{Al}_{2} \mathrm{O}_{3} \cdot \mathrm{H}_{3} \mathrm{O}\right)$. Some metal chunks that could not be ground had to be removed prior to analysis. The metal chunks probably comprise the "black spheres and odd shapes" described later in this report.

\section{Elemental Analysis}

The total chlorine content, determined by neutron activation analysis, of both the fines $(<50 \mathrm{ppm})$ and the filtered residue $(<5 \mathrm{ppm})$ were below the limits of detection. Sensitivity is dependent upon sample size. The lower sensitivity for the filtered solids reflects the larger sample available for analysis.

The primary means of identifying elemental constituents in the solids was the Scanning Electron Microscopy/Energy Dispersive Spectroscopy (SEM/EDS) analysis. This technique consists of an SEM scan of a small area on the sample, which produces the EDS spectrum with peaks characteristic of the elements present. Scans were made of typical and of unusual areas in each sample. Major elements found were, as expected, aluminum and iron (from stainless steel).

Selected SEM photomicrographs, with a bar-graph interpretation to infer relative amounts of each element, are presented in Figure 3 and beyond. The EDS spectra have been converted as shown to bars with numerical values that correspond to the relative sizes of the peaks, which are roughly proportional to the amount of the element present. The scale in microns or millimeters is shown at the bcttom of each picture.

Results of the SEM/EDS analysis for the fines that passed through the filter are shown in Figure 3. The material contained mostly aluminum, with one spot (C) that showed iron as a major component. Minor amounts of sulfur were present in most of the spots examined $(A, B, D, H, I, J)$. This unexpected result has been attributed to sulfate from disassembly basin water, or from deionizer resins. Sulfur content of the filtered material was insignificant. Another view (not shewn) revealed two flecks of copper in these fines.

The color phot,ograph of the filtered residue, Figure 4, shows that it was a collection of several types of material. This conglomerate was first examined as a whole to determine the overall composition. Then six fractions were manually 
separated, based on their appearance, and these fractions were examined individually. The two fractions, called "yellow flakes" and "black spheres and odd shapes" are presented here in detail. The others, namely, red, white, tan, and gray flakes, are included in the summary Table 7.

Figure 5 shows the SEM photograph and the EDS bar chart for the filtered conglomerate. Stainless steel, with the Fe-Cr-Ni signature, was present in Spots A and F. Other spots (C,D,E,H,I) showed mostly aluminum. Spot B showed both aluminum and iron. Spot $\mathrm{G}$ showed mostly silicon, with some aluminum. Only a trace of sulfur was detected (C,I).

Figure 6 shows SEM/EDS results for the yellow flakes, the predominant component of the residue. These flakes were up to $3 \mathrm{~mm}$ in cross-section and about 20 $\mu \mathrm{m}$ thick. The flakes were smooth on one side and rough on the other; the larger area of the right photograph presents the rough side. These yellow flakes contained primarily aluminum (C,D), with some stainless steel (A). Uranium, with aluminum and phosphorus, was found at spot $B$.

Figure 7 shows two views of the fraction called "black spheres and odd shapes". These were different in appearance from the other materials, which looked like corrosion products. The size is the order of millimeters. The relatively small proportion of these pieces make them of little real concern, but they may indeed be artifacts.

Figure 8 shows SEM/EDS results for the "black spheres and odd shapes." These pieces showed the stainless steel signature $(A, D, E)$, and one spot $(C)$ showed iron and chromium without the nickel. Two spots $(B, G)$ showed chromium enrichment, and the surface looked etched. One spot $(F)$ showed thorium with smaller amounts of aluminum, iron, and chromium.

The elemental composition of the fines and of the separated components of the filtered residue, determined by the SEM/EDS, are summarized in Table 7. Except for the pervasive sulfur and the flecks of copper in the fines, the two samples were similar.

\section{Discussion of Results}

A summary of the elements identified by SEM/EDS, with conjectures about possible origins, is given in Table 8.

- Aluminum and iron compounds (and the nickel and chromium of stainless steel) would be indigenous to the reactor primary system.

- Other elements, such as thorium and uranium, along with the curium and plutonium alpha emitters, reflect past operating history and indicate some deposits may very old. 
- Silica may have come from the Al-Si bonding in the manufacture of natural uranium fuel slugs, or as residue from lithium silicate added at one time as a corrosion inhibitor ${ }^{(4)}$ in the 1960 's, or from an outside source.

- Perhaps phosphorus is a carryover from a heat exchanger in K-Reactor that was cleaned with phosphoric acid, with prolonged retention of phosphorus ${ }^{(4)}$, in the mid-1960's.

- The copper flecks in the fines represent a miniscule amount of copper in the system. Because copper may promote galvanic corrosion of aluminum cladding of the fuel and target elements, the copper content of the moderator is routinely monitored at less than $25 \mathrm{ppb}^{(5)}$, but these copper flecks would likely be undetected since they are not dissolved. They may have come from copper electrical wiring.

- The sulfur in the fines might come from the deionizer resins; however, since there was only a trace in the filtered residue, the sulfur (as sulfate) has been attributed to contact with disassembly basin water.

- Chromium-enrichment in some "black spheres and odd shapes" may be caused by preferential dissolution of iron in the stainless steel by oxygenated water, to leave a chromium-rich film ${ }^{(6)}$; or it may have been a chrome-plated artifact.

The low chlorine content found by neutron activation indicates that chloride is not concentrating in these in-tank deposits. The possible presence of chloride in the debris was of concern because analyses in the 1960's had shown chloride concentrations of 10 to $10,000 \mathrm{ppm}$ in gibbsite deposited on stainless steel surfaces outside the reactor tank. (7) Alumina is a known scavenger for chloride and other ions.

The yellow flakes comprised the majority of the material. Their morphology, with a smooth side and a rough side, suggests they may have have flaked off a surface. A likely surface is the tank wall; perhaps flaking occurred during the UT inspection. The fact that the majority of the crystalline alumina was gibbsite, the lowtemperature alumina, would indicate a cooler origin than the surface of a fuel assembly.

Nothing was found in this debris that would indicate untoward corrosion or reactor chemistry problems. This material probably settled out during the stagnant or semi-stagnant period of the UT inspection. In video pictures of the vacuuming operation, the material appeared to be easily dispersed. Therefore when the pumps are on, this material would be expected to be swept from the tank bottom into the bulk moderator, and then removed by the purification system and the evaporator.

ACKNOWLEDGMENT: The assistance of D.Z. Nelson who made all the arrangements for receipt and sampling of the filter assembly at SRL is gratefully acknowledged. 
WSRC-TR-92-027

\section{REAERENCES}

1. D.C. Patterson, Drawing S5-1-8327, Process Area Vacuum Tool Assembly, March 19, 1990.

2. R.C. Hochel, Results for K-Area Moderator Samples 29817 and 29818, SRLADS-89-0192 (August 25, 1989).

3. N.P. Baumann, Origin of Alpha Activity in K-Reactor Moderator, NEDP-89-07 (July 28, 1989).

4. F.B. Longtin, Reactor Chemistry and Radioactivity Manual, RTR-1806 (August 1978), p. 66(Si), p. 98(P).

5. DPSOL 105-6101A-PLK, Sample Analysis Schedule and Control System-SANSCO, 07/23/91

6. I. Olefjord and H. Fischmeister, ESCA Studies of the Composition Profile of Low Temperature Oxide Formed on Chromium Steels--II. Corrosion in Oxygenated Water, Corrosion Science 15, 697-701 (1975).

7. R.S. Ondrejcin, A Mechanism for Stress Corrosion Cracking of Stainless Steel in Reactor Systems, DP-1089 (December 1969).

8. E.W. Baumann, SRS Laboratory Notebook WSRC-NB-91-189. 


\section{Table 1}

\section{SUMMARY OF ANALYSES PERFORMED}

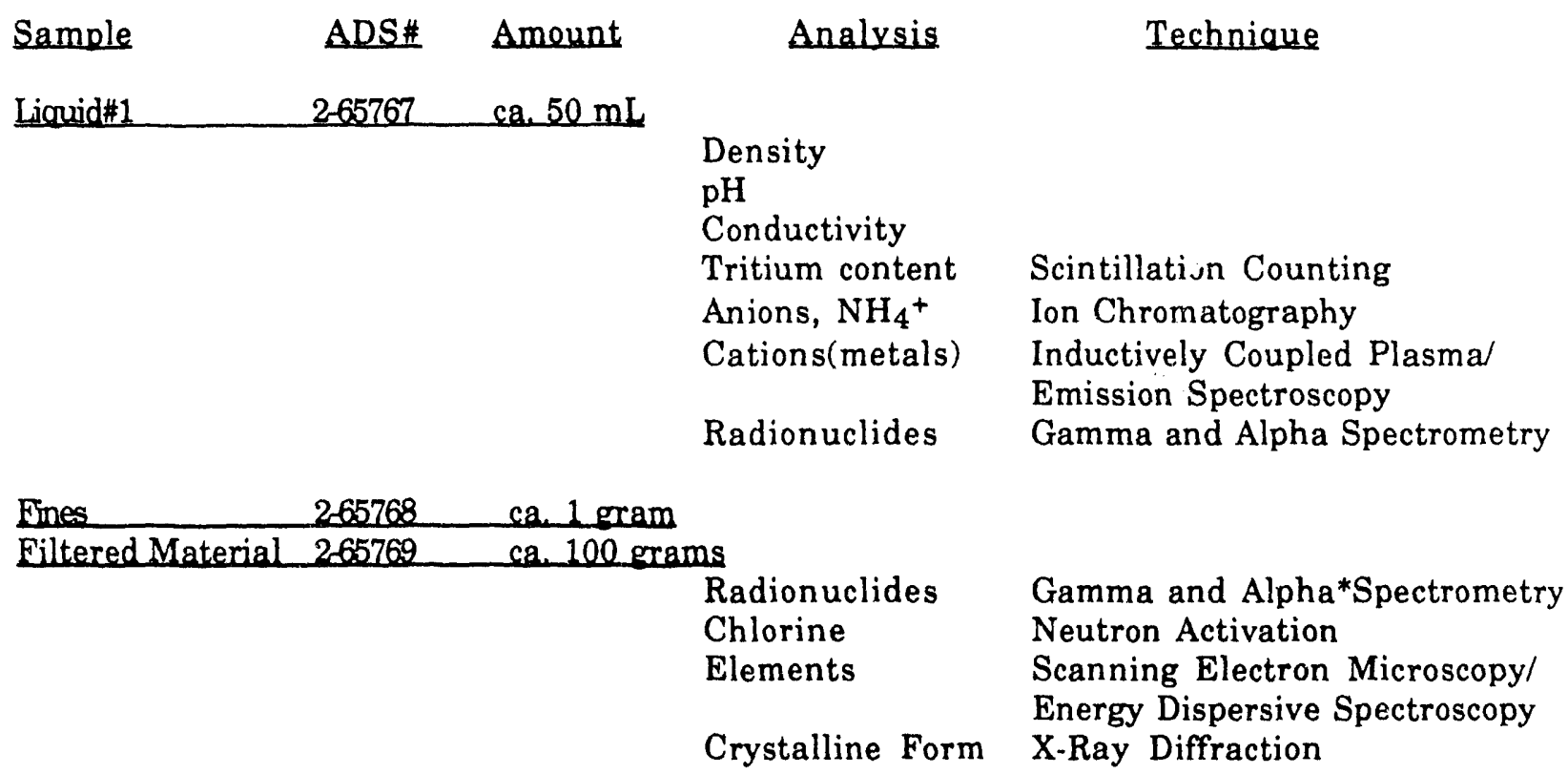

*Alpha Spectrometry on filtered material only.

Table 2

MUSCELLANEOUS ANALYSES OF LIQUTD

$\begin{array}{lll}\text { Analysis } & \text { Result } & \text { Units } \\ \text { pH } & 6.8 & \\ \text { Density } & 1.01 & \mathrm{~g} / \mathrm{mL} \\ \text { Conductivity } & 219 & \mu \mathrm{mho} / \mathrm{cm}\end{array}$


Table 3
RADIONUCLIDES IN LIQUID SAMPLE

\begin{tabular}{|c|c|c|c|c|}
\hline Radionuclide & Half-life & Filtered & Unfiltered & Units \\
\hline Co-60 & $5.3 y$ & $1.90 \mathrm{E}-4$ & $5.33 \mathrm{E}-3$ & $\mu \mathrm{Ci} / \mathrm{mL}^{\mathrm{a}}$ \\
\hline Cs-137 & $30 y$ & $2.30 \mathrm{E}-4$ & $2.36 \mathrm{E}-4$ & $\mu \mathrm{Ci} / \mathrm{mL}$ \\
\hline $\mathrm{Ru}-106$ & $368 \mathrm{~d}$ & & $9 \mathrm{E}-4$ & $\mu \mathrm{Ci} / \mathrm{mL}$ \\
\hline Cs-134 & $2.1 \mathrm{y}$ & & $2.99 \mathrm{E}-4$ & $\mu \mathrm{Ci} / \mathrm{mL}$ \\
\hline $\mathrm{H}-3$ & $12.3 \mathrm{y}$ & 1.41 & & $\mu \mathrm{Ci} / \mathrm{mL}$ \\
\hline Alpha & & None det & & \\
\hline
\end{tabular}

a. Micro Curies per milliliter

\section{Table 4}

CHEMICAL CONTENT OF LIQUID

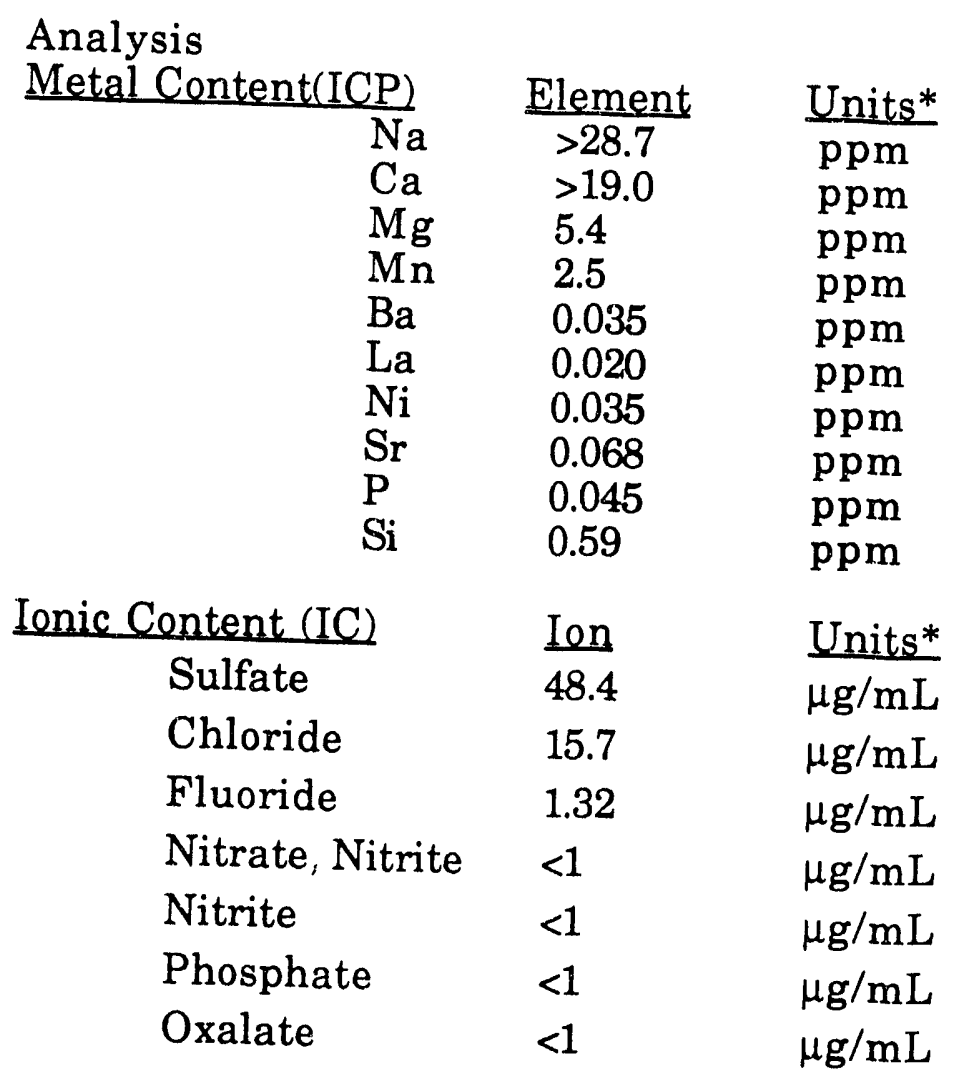

*Units are as reported; for light water ppm (parts per million) is the same as $\mu \mathrm{g} / \mathrm{mL}$. 


\section{Table 5
GAMMA ACTIVITY IN SOLIDS}

$\begin{array}{lllll}\text { Radionuclide } & \text { Half-life } & \text { Fines } & \text { Filtered } & \text { Units } \\ \text { Co-60 } & 5.3 \mathrm{y} & & & \\ \text { Ru-106 } & 368 \mathrm{~d} & 2.55 \mathrm{E}-1 & 3.85 \mathrm{E}-1 & \mu \mathrm{Ci} / \mathrm{g}^{\mathrm{a}} \\ \mathrm{Zn}-65 & 245 \mathrm{~d} & 1.05 \mathrm{E}-2 & 7.05 \mathrm{E}-2 & \mu \mathrm{Ci} / \mathrm{g} \\ \mathrm{Ce}-144 & 284 \mathrm{~d} & 9.48 \mathrm{E}-3 & 3.77 \mathrm{E}-2 & \mu \mathrm{Ci} / \mathrm{g} \\ \text { Eu-154 } & 16 \mathrm{y} & 1.02 \mathrm{E}-3 & 3.56 \mathrm{E}-3 & \mu \mathrm{Ci} / \mathrm{g} \\ \text { Cs-137 } & 30 \mathrm{y} & 2.29 \mathrm{E}-3 & \text { not found } & \mu \mathrm{Ci} / \mathrm{g} \\ & & & & \end{array}$

a. Micro Curies per gram

\section{Table 6
ALPHA ACTIVITY IN FILTERED SOLIDS}

\begin{tabular}{llllll} 
& Half-life & Leached(a) & & \multicolumn{3}{c}{ Dissolved(b) } & $\begin{array}{l}\text { In Moderator } \\
\text { AUG-89(2.3) }\end{array}$ & Units \\
Gross Count & & $2.2 \mathrm{E} 5$ & $>8.85 \mathrm{E} 6$ & & $\mathrm{~d}$ \\
$\mathrm{Pu}-239,240$ & $>6600 \mathrm{y}$ & 2.6 & 49.9 & 35 & $\%$ \\
$\mathrm{Pu}-238$ & $86 \mathrm{y}$ & 8.6 & 19.7 & 8 & $\%$ \\
$\mathrm{Cm}-244$ & $18 \mathrm{y}$ & 87.1 & 30.3 & 31 & $\%$ \\
$\mathrm{Cm}-242$ & $0.4 \mathrm{y}$ & 1.7 & $\leq 0.6$ & 26 & $\%$
\end{tabular}

\footnotetext{
a. $0.65 \mathrm{~g}$ leached with $2 \mathrm{mi} 8 \mathrm{M}$ nitric acid

b. $0.25 \mathrm{~g}$ mostly dissolved in $2 \mathrm{~mL} 12 \mathrm{M} \mathrm{HCl}, 1-2$ drops of concentrated hydrofluoric and nitric c. Disintegrations per minute per gram.
} 


\section{Table 7 \\ SUMMARY OF SEM/EDS ANALYSES}

\section{Sample}

Fines

Filtered Residue

Conglomerate

Black Spheres

\& Odd Shapes

Yellow Flakes

Red Flake

Gray Flake

White Flake

Tan Flakes

\begin{tabular}{clll}
\multicolumn{4}{c}{ Elemental Analysis } \\
\hline Principal & Minor & Also Seen & Size \\
Al & $\mathrm{Fe}, \mathrm{S}$ & $\mathrm{Cr}, \mathrm{Si}(\mathrm{Cu})$ &
\end{tabular}
$\mathrm{Al}, \mathrm{Fe}$
$\mathrm{Cr}, \mathrm{Ni}$
$\mathrm{Cr}, \mathrm{Fe}$
$\mathrm{Ni}$
Th
$2-3 \mathrm{~mm}$
$\mathrm{Al}, \mathrm{Fe}$
$\mathrm{Cr}, \mathrm{Ni}$
$\mathrm{U}, \mathrm{P}$
$<3 \mathrm{~mm}$
$\mathrm{Fe}$
Al
$\mathrm{Si}$
ca. $0.5 \mathrm{~mm}$
$\mathrm{Fe}$
$\mathrm{Cr}, \mathrm{Ni}, \mathrm{Al}$
ca. $0.2 \mathrm{~mm}$
$\mathrm{Al}, \mathrm{Fe}$
ca. $3 \mathrm{~mm}$
$\mathrm{Al}, \mathrm{Fe}$
$\mathrm{Cr}, \mathrm{Ni}$
$\mathrm{Si}$
2-3 mm

Table 8

SUMMARY OF PROBABLE SOURCES

Found

Aluminum

Iron, Chromium, Nickel

Silicon

Trace of Uranium

Trace of Thorium

Trace of Phosphorus

Trace of Copper in Fines

Enhanced Chromium

Sulfur in Fines
Probable Source

Fuel/Target Cladding and $\mathrm{Al}$ Components

Deposits on Tank Wall

Stainless Steel Tank and Piping

Al-Si Bonding of uranium metal fuel; glass; sand

Fuel or Uranium targets

Th irradiations

Unknown; heat exchanger cleaning?

Unknown; electrical wire?

Selective etching of stainless steel; chromeplate?

Unknown; basin water? resin? 


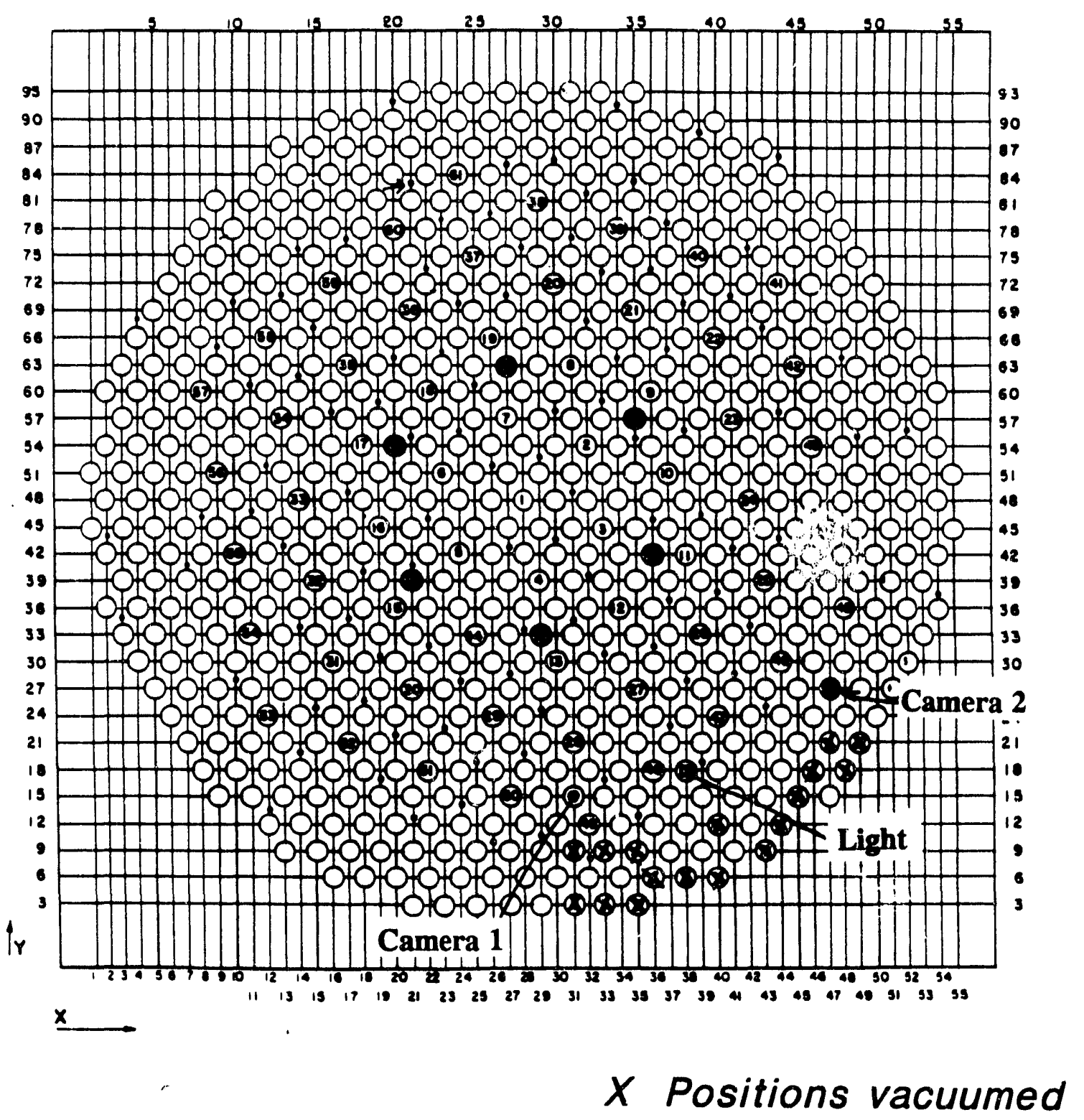

Figure 1. Reactor Face Map Showing Positions Vacuumed 
WSRC-TR-92-027

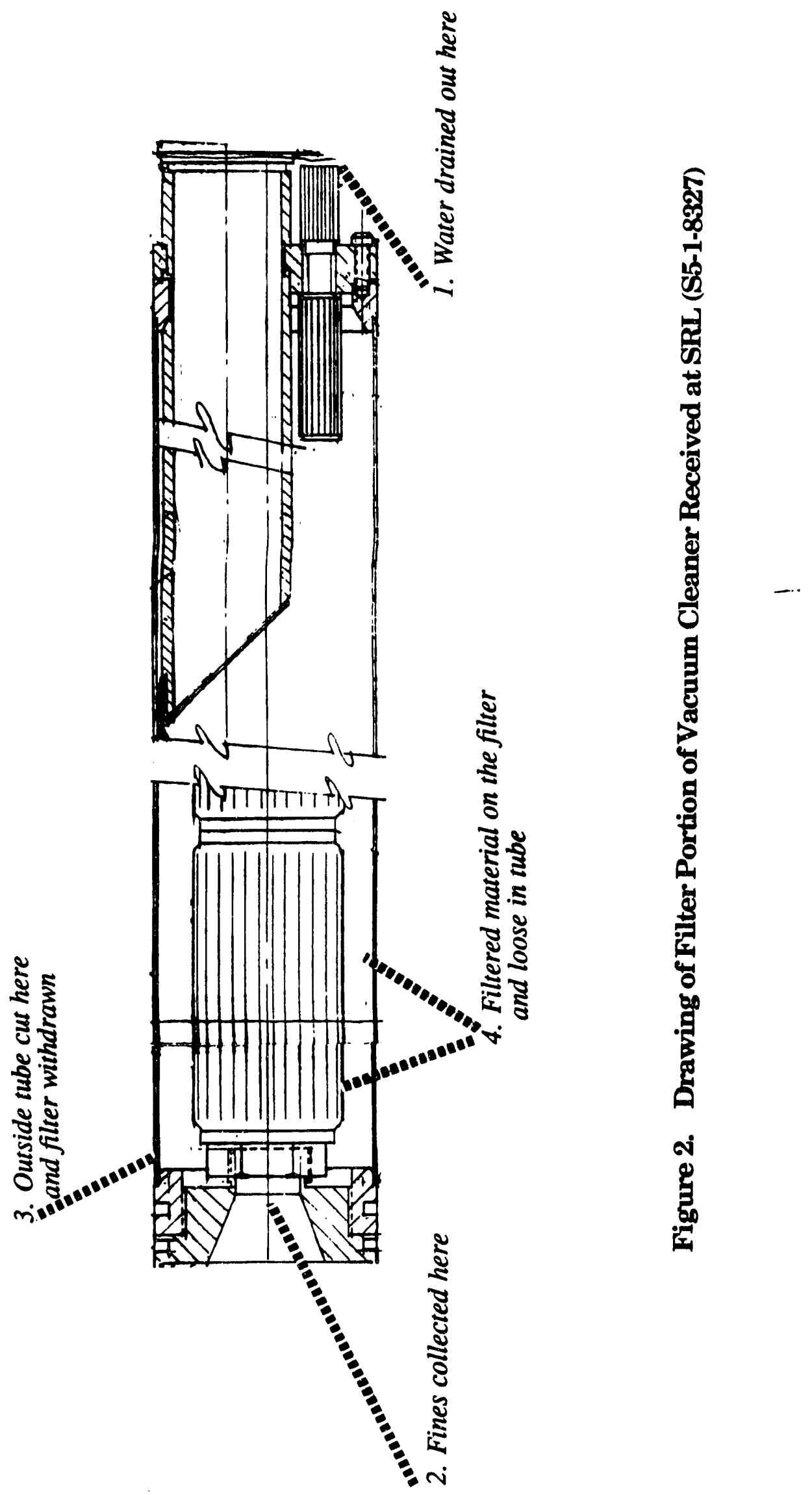

Page 13 of 19 


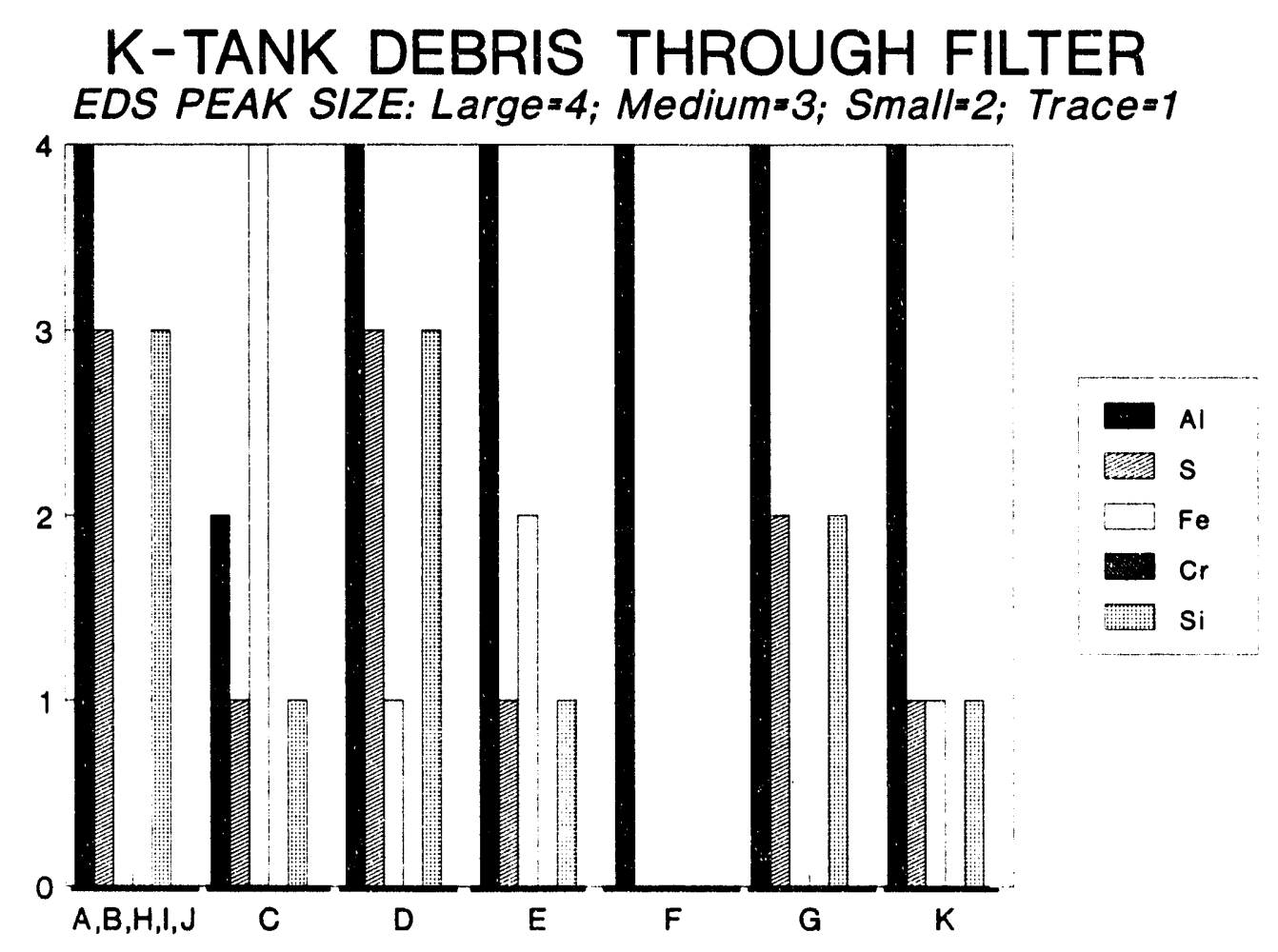

Figure 3. SEM/EDS of Fines That Passed Through Filter 


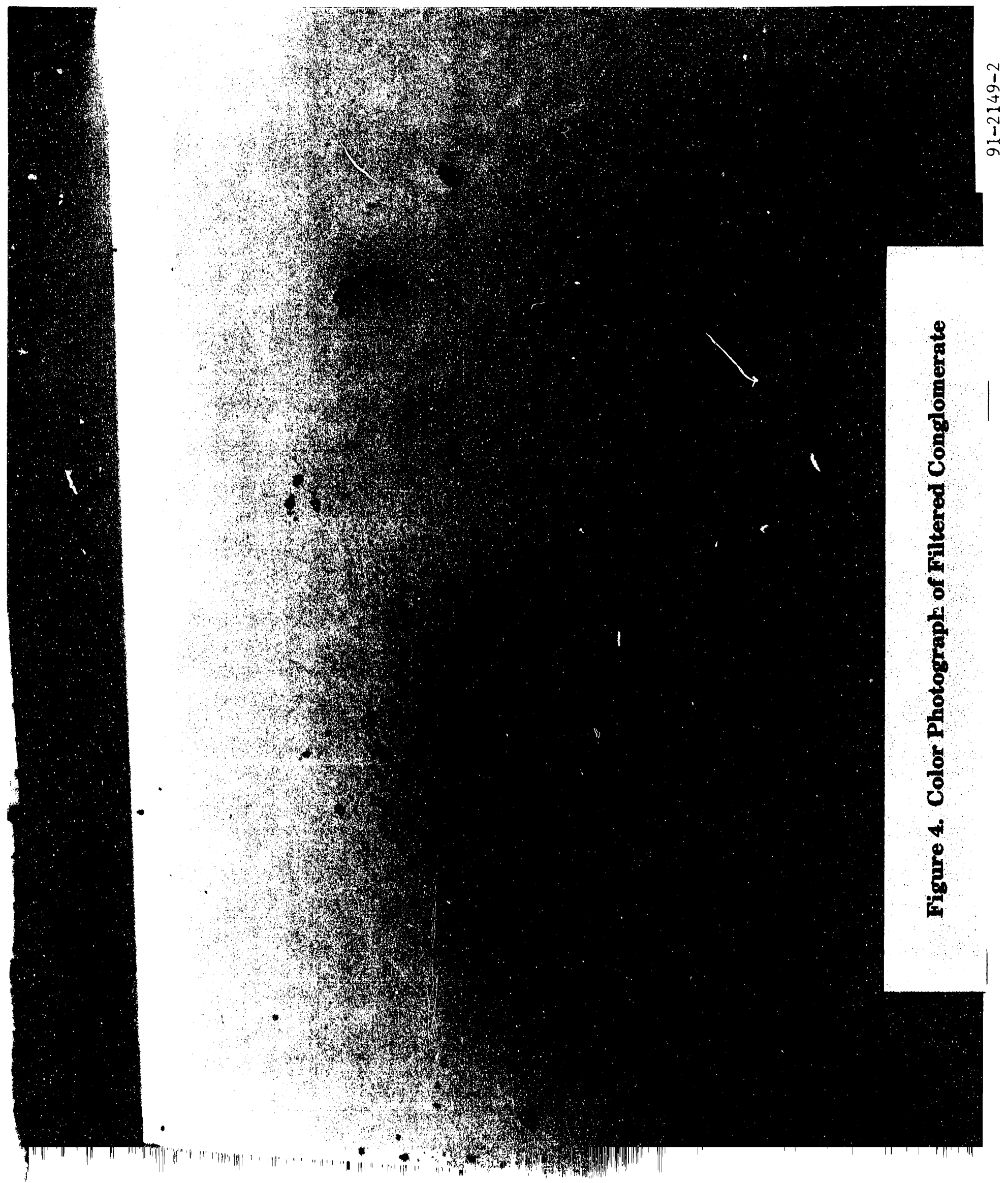


CONGLOMERATE

EDS PEAK SIZ.E: Large $=4$; Medium $=3$; Small $=2$; Trace $=1$

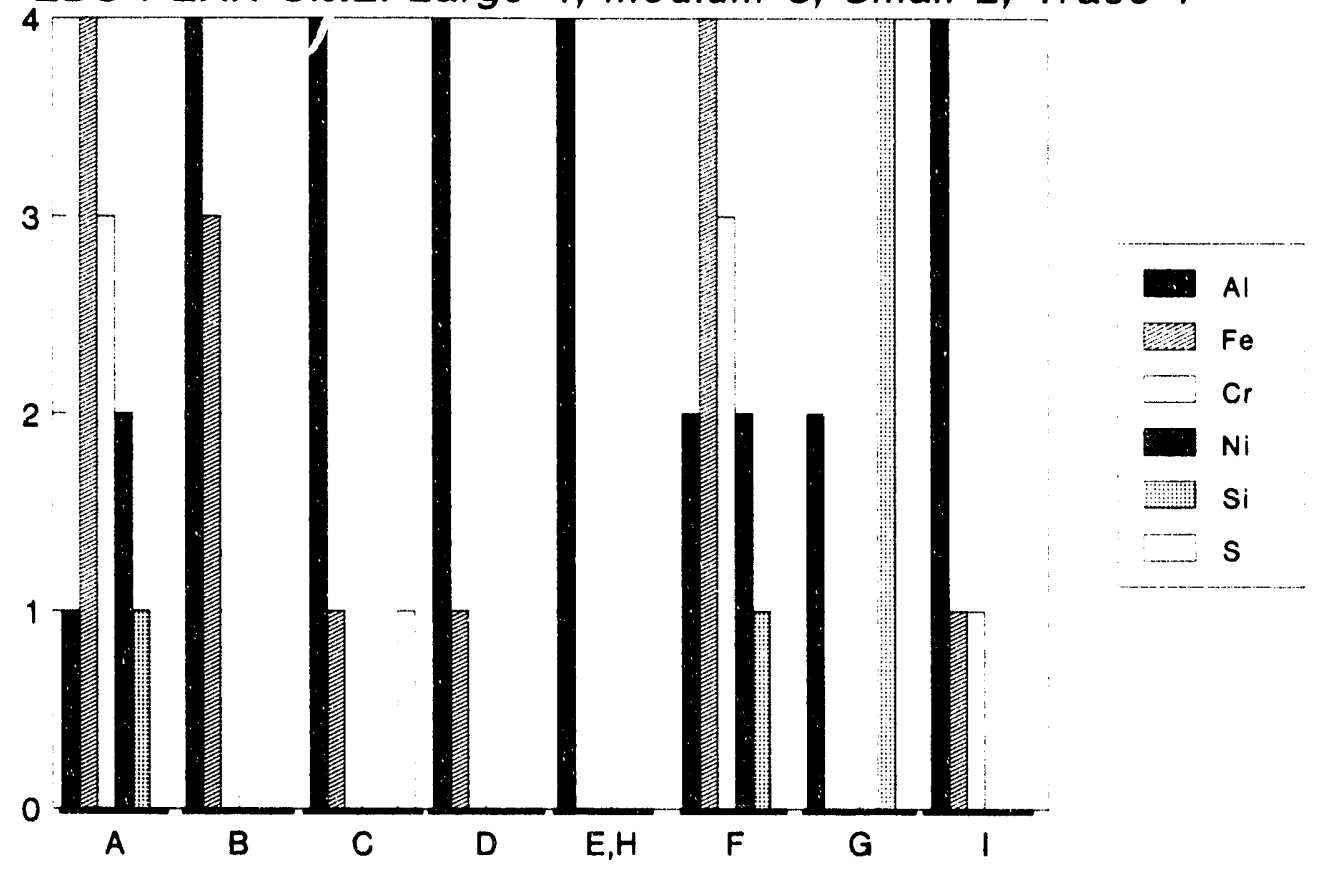

Figure 5. SEM/EDS of Filtered Conglomerate 

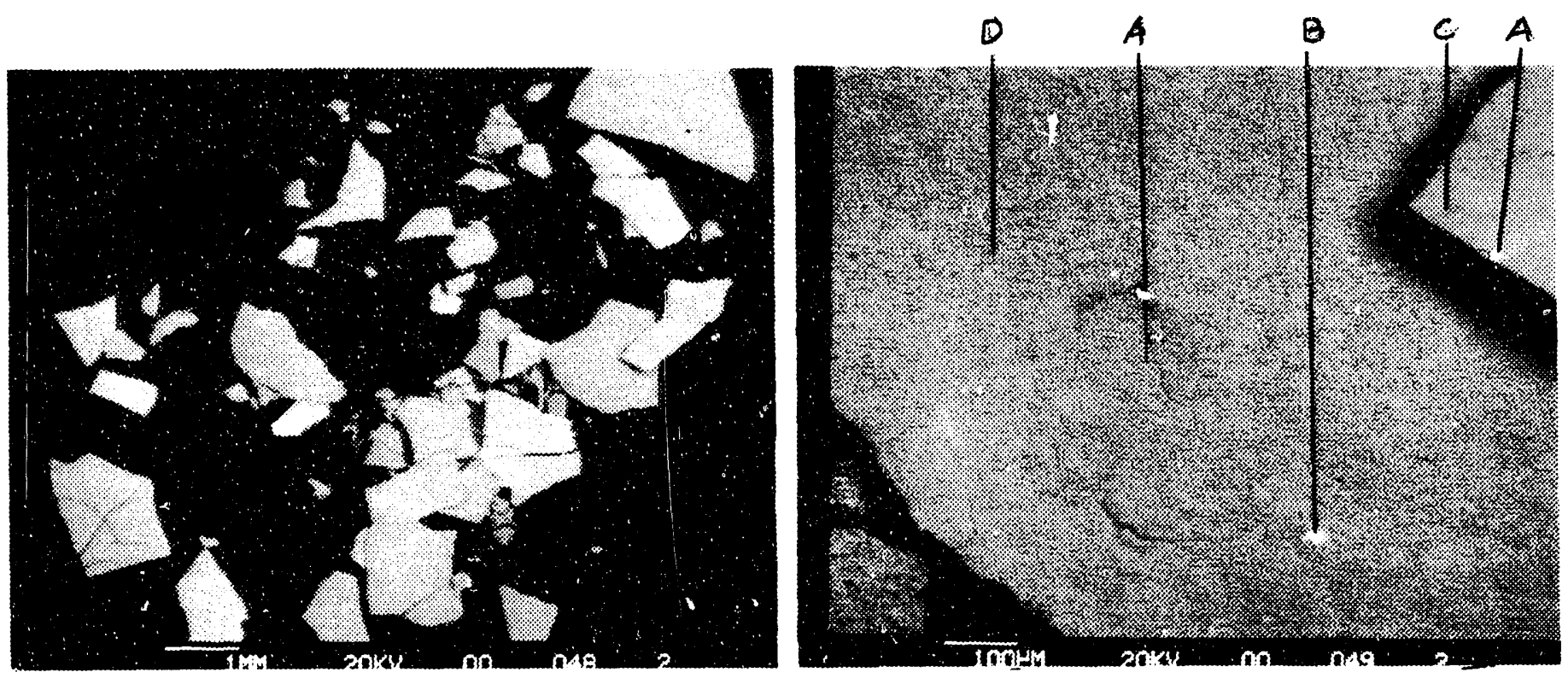

\section{YELLOW FLAKES}

EDSPEAK SIZE: Large=4; Medium=3; Small=2; Trace=1
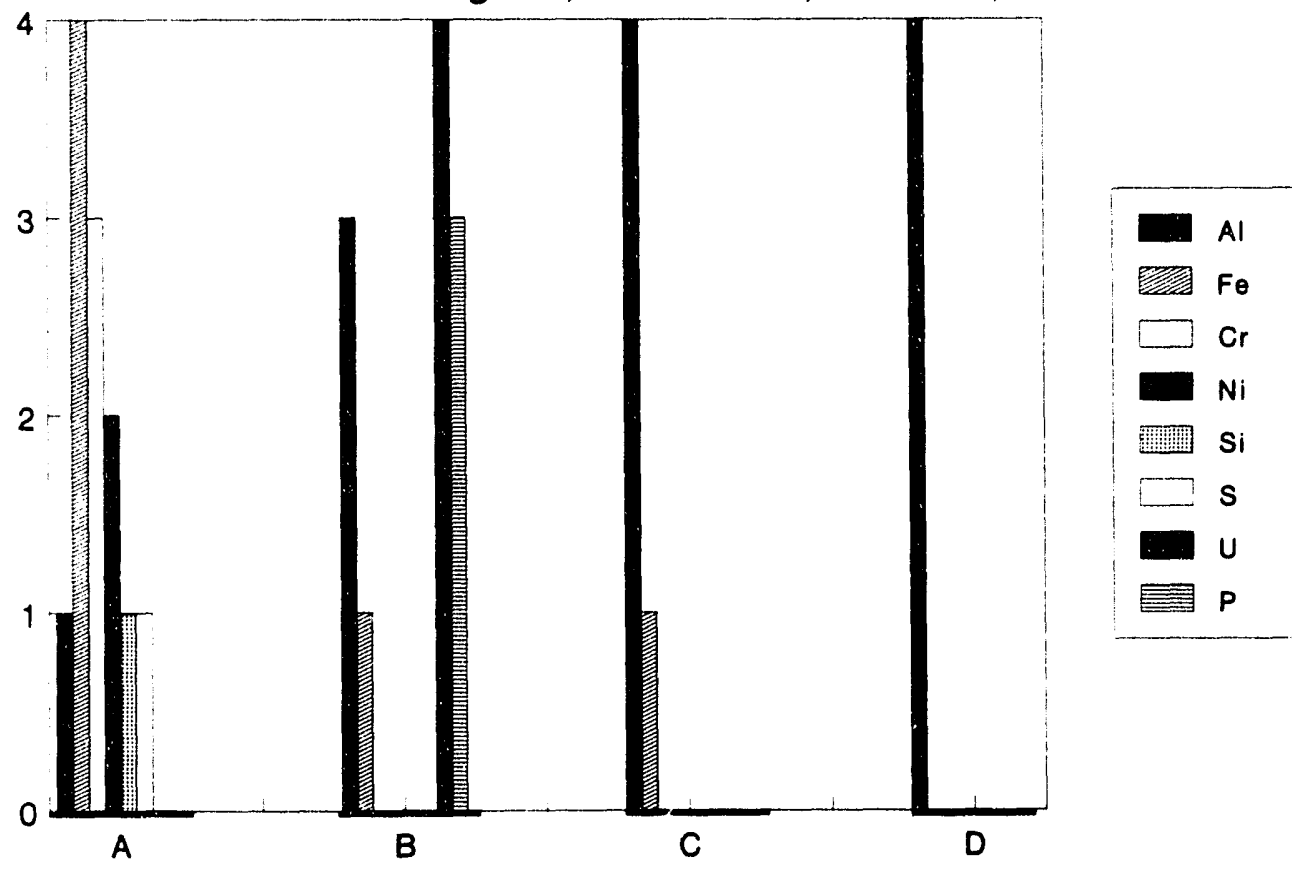

Figure 6. SEM/EDS of Yellow Flakes 

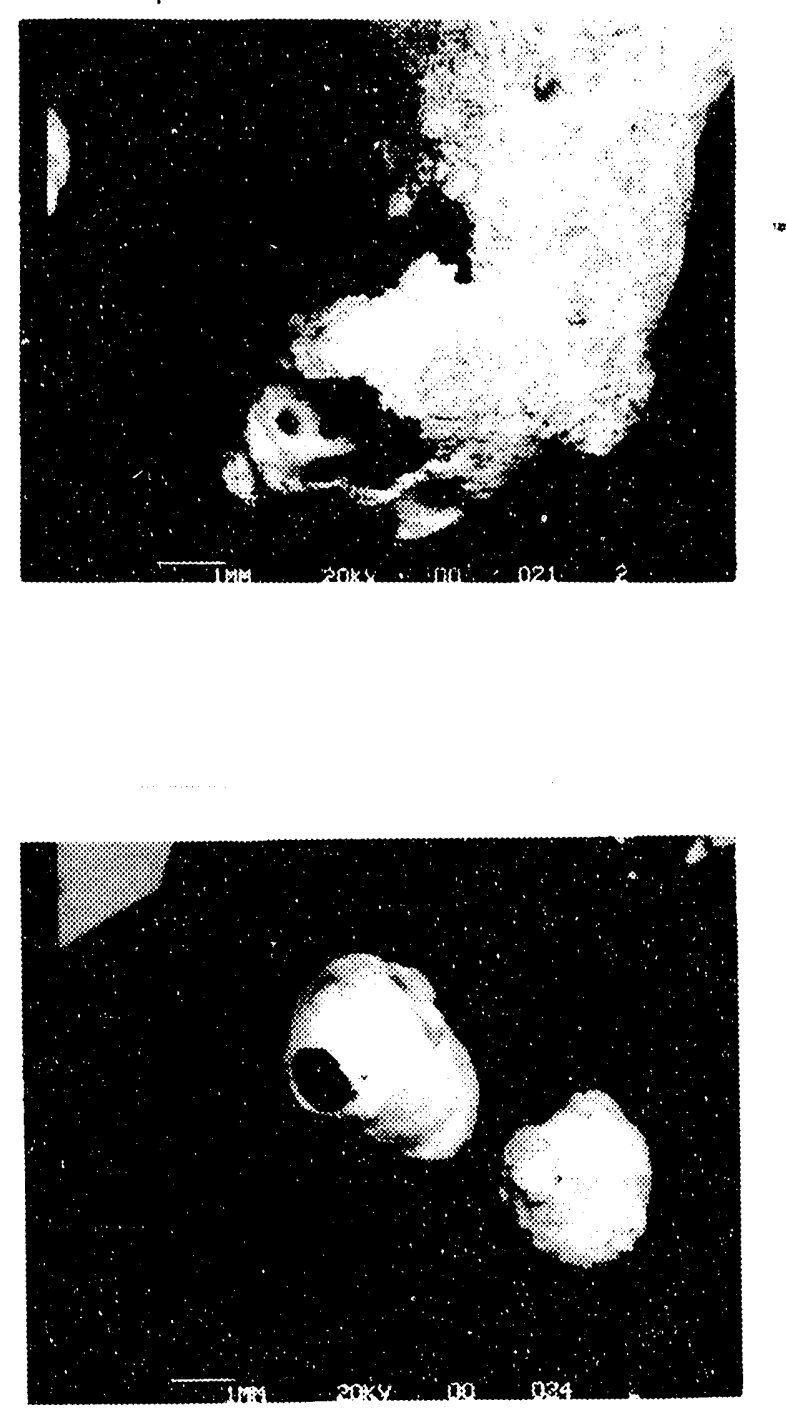

Figure 7. Typical Black Spheres and Odd Shapes

Page 18 of 19 

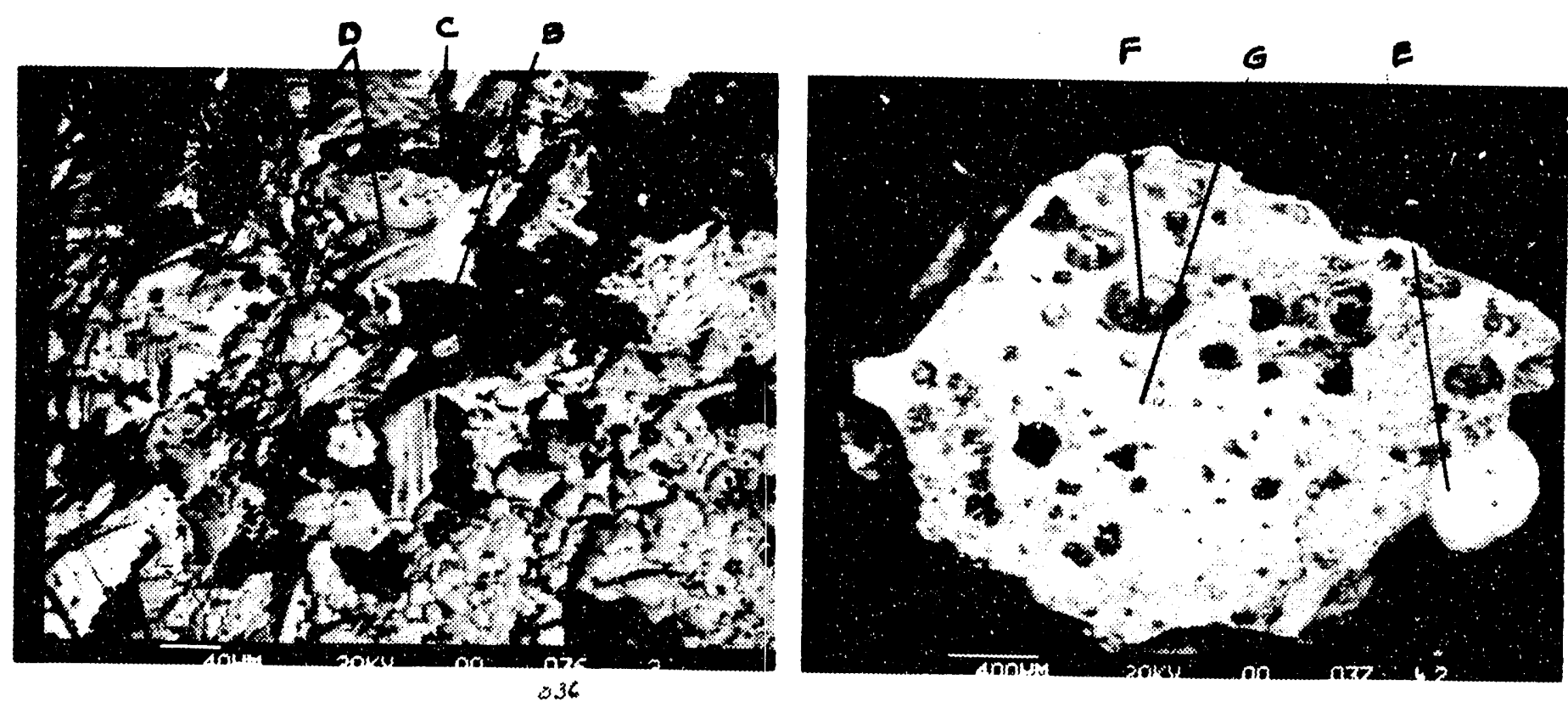

\section{BLACK SPHERES AND ODD SHAPES}

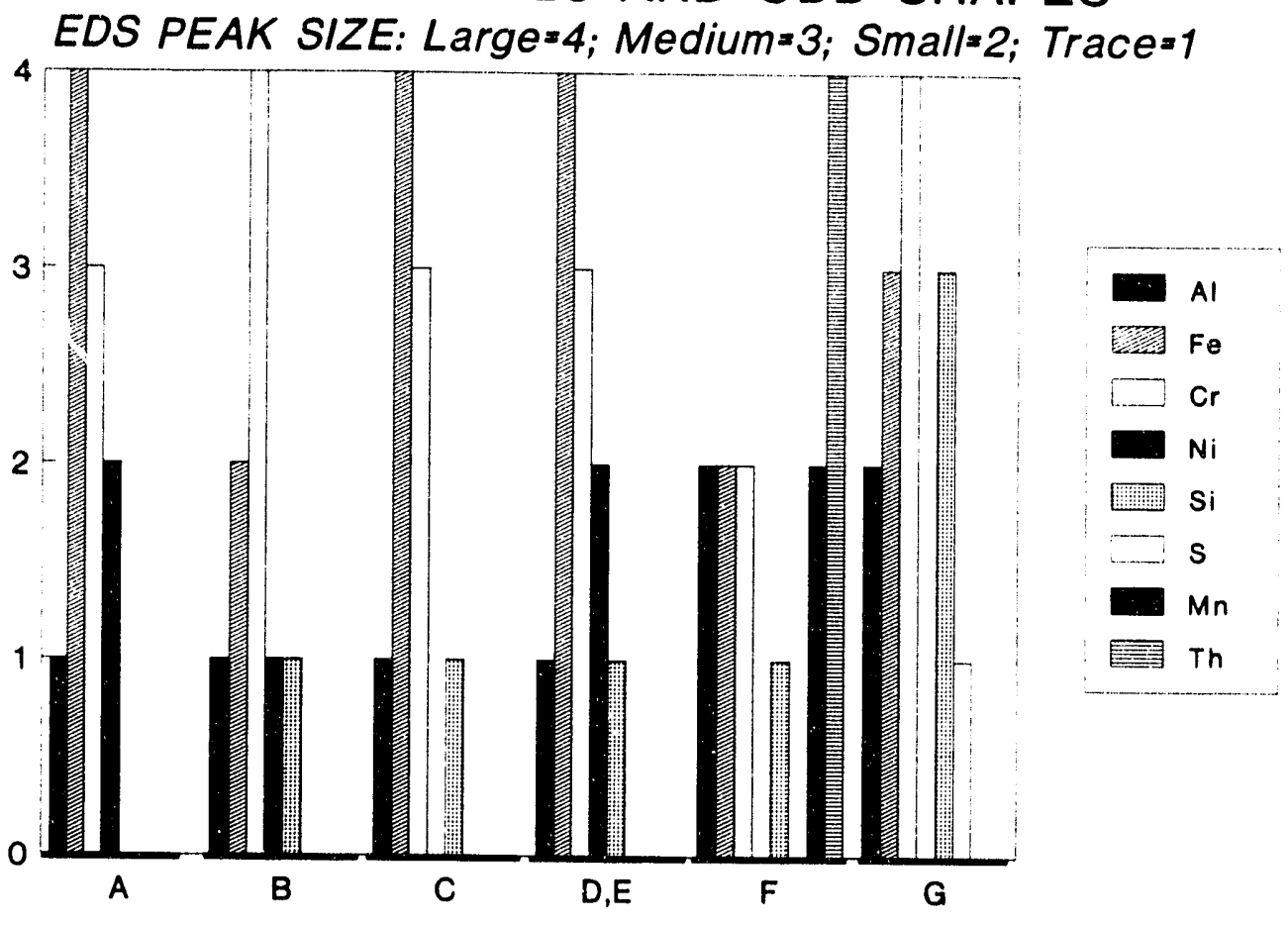

Figure 8. SEM/EDS of Black Spheres and Odd Shapes 

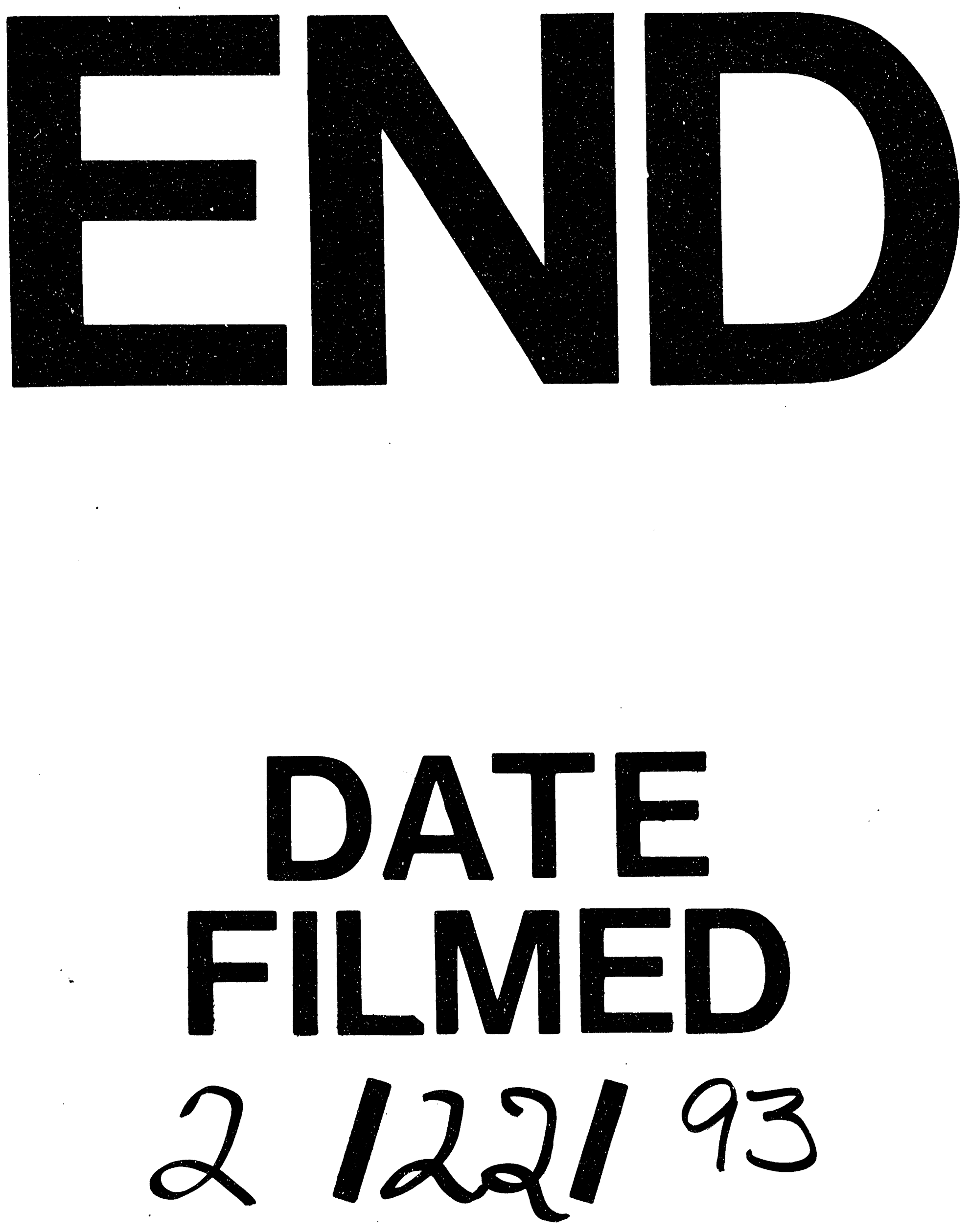
